\title{
EFFECTS OF BETAINE ON ENERGY UTILIZATION IN GROWING PIGS - A REVIEW
}

\author{
Krzysztof Lipiński ${ }^{1}$, Ewa Szramko ${ }^{1}$, Heinz Jeroch ${ }^{2}$, \\ Paulius Matusevičius ${ }^{2}$ \\ ${ }^{1}$ Department of Animal Nutrition and Feed Management, University of Warmia and Mazury \\ in Olsztyn, Oczapowskiego 5, 10-718 Olsztyn-Kortowo, Poland \\ ${ }^{2}$ Department of Animal Science, Veterinary Academy of Lithuanian University of Health Sciences, \\ Tilzes 18, LT-47181, Kaunas, Lithuania \\ Corresponding author: krzysztof.lipinski@uwm.edu.pl
}

\begin{abstract}
One of the well known biological functions of betaine is that of a methyl donor. Therefore, betaine may partly replace choline and methionine in the diet. Another widely documented role of betaine is to restore and maintain the osmotic balance. As an organic osmotic compound, betaine regulates the water balance, thus exerting a stabilizing influence on tissue metabolism, particularly within the digestive tract. As a donor of methyl groups necessary for various reactions in the body, betaine is indirectly involved in lipid metabolism. Due to its metabolic functions, betaine is also believed to play a significant role in energy metabolism in pigs. Of particular note are the results of experiments in which a positive effect of betaine supplementation was observed as the energy content of the diet was decreased.
\end{abstract}

Key words: betaine, growing pigs, energy utilization

Energy supplied by feed is used by the body for maintenance and production purposes. Cereals are the main energy source in diets for pigs. The energy concentrations in the ration may be also increased by adding fat to feed; however, a rise in energy levels achieved in this way is limited by physiological and technological factors. The energy content of the ration may be also increased by the administration of feed additives, including feed enzymes.

Using an alternative approach, additional energy can be obtained through precise control over metabolic processes in the body. The knowledge of physiological processes at the level of cell metabolism makes it possible to influence body protein (muscular tissue) or fat deposition using substances that impact protein and fat metabolism. Previous investigations suggest that betaine supplementation may contribute to attaining the above goal in pigs (Szramko et al., 2006 a). Some authors have pointed out the fact that the effect of betaine is greater when it is added to diets 
containing low concentrations of energy, since it enables to save part of maintenance energy which can be used for production purposes or withdrawn from the diet when the pigs have fully reached their genetic production potential (Casarin et al., 1997; Cromwell et al., 2000; Schrama et al., 2001, 2003).

\section{Physiological functions of betaine}

Betaine is widely synthesized in animal and plant tissues, as well as in microorganisms. Rich dietary sources of betaine are marine invertebrates, wheat germ, wheat bran, rapeseed, spinach and sugar beets. Betaine was first discovered in the juice of sugar beets (Beta vulgaris) in the 19th century (Craig, 2004; Le Rudulier et al., 1984; Zeisel et al., 2003). Betaines are a group of methyl derivatives of glycine. Betaine, similarly to carnitine and choline, is a quaternary amine. Betaine has been classified as a methylamine because it contains three chemically reactive methyl groups linked to the nitrogen atom. Betaine has a molecular weight of 117.2 Da, is thermally stable up to $200^{\circ} \mathrm{C}$, and highly water soluble due to its electric charge and the presence of polar functional groups (Odle et al., 2000).

As a product of choline oxidation, betaine is a source of methyl groups participating in metabolic processes in animals. Another physiological function of betaine is to protect cells against undesirable changes in osmotic pressure. Betaine is involved in a variety of biochemical reactions important for vital functions, and its metabolism is closely linked to that of methionine and choline (Eklund et al., 2005; Lowry et al., 1987; Puchala et al., 1998; Saunderson and MacKinlay, 1990). Betaine also promotes growth by enhancing GH secretion in pigs (Huang et al., 2007).

\section{Methyl donor}

Prior to its conversion to betaine in a two-step enzymatic process, choline must be transported from the cytoplasm to the mitochondrion, where it is oxidized to betaine aldehyde in a reaction catalyzed by the enzyme choline oxidase. Betaine aldehyde is further oxidized to betaine by the enzyme betaine aldehyde dehydrogenase $(\mathrm{BADH})$. Thus, betaine is a direct donor of methyl groups only when transferred to the cytoplasm. The transfer is a complex and energy-consuming process (Simon, 1999; Virtanen, 1995), the effectiveness of which may be limited by factors disturbing transport between the cell membrane and mitochondria. These factors include ionophores given to poultry to control the parasitic disease coccidiosis.

Betaine is catabolized via a series of enzymatic reactions that take place mostly in the mitochondria of liver and kidney cells. The main goal of this conversion is to donate methyl groups for the production of methionine and its active form, Sadenosylmethionine (SAM), and to detoxify homocysteine (HC). The process may occur via two different metabolic pathways, with $\mathrm{HC}$ as a common component of both (Craig, 2004). The enzyme betaine-homocysteine methyltransferase (BHMT) catalyzes the transfer of only one methyl group from betaine to homocysteine, to form methionine. This pathway, known as the transmethylation cycle, was described by Finkelstein and Martin (1984, 1986). Hepatic betaine-homocysteine methyltransferase (BHMT) activity was significantly increased by $13.97 \%(\mathrm{P}<0.05)$ when pigs were offered $0.125 \%$ betaine (Feng et al., 2006). The remaining methyl groups are 
transferred to dimethylglycine (DMG) and monomethylglycine (sarcosine) which are converted into homocysteine via the vitamin $\mathrm{B}_{12}$-dependent enzyme 5-methyltetrahydrofolate-homocysteine methyltransferase (MFHT), and then they are used for methionine production (Odle et al., 2000).

As already mentioned, methyl groups are indispensable for metabolic processes (e.g. methylation of nucleic acids, biosynthesis of creatine, carnitine and choline). It has been also demonstrated that an adequate supply of available methyl groups enhances the immune response (Swain and Johri, 2000). However, the vertebrates are unable to synthesize methyl groups, and must obtain them from the diet. In farm animals the main sources of methyl groups are choline, methionine and betaine. Research results show that among those three compounds betaine is the most effective methyl donor. The estimation of the metabolic rate within living organisms poses certain problems, but it was calculated that $1 \mathrm{~kg}$ of anhydrous betaine $(97 \%)$ supplies the equivalent amounts of methyl groups as $1.25 \mathrm{~kg}$ of DL-methionine or $1.65 \mathrm{~kg}$ of choline chloride (70\%) (Kidd et al., 1997). This suggests that betaine can partly or totally replace synthetic choline (Partridge, 2003) and partly replace synthetic methionine in the ration, thus reducing overall feed costs (Remus and Virtanen, 1996). According to some authors (Overland et al., 1999), the use of betaine as a methyl group donor is associated with the methionine-sparing effect, making methionine more available for other metabolic functions (e.g. for protein synthesis, where betaine cannot be substituted for methionine).

Similarly as methionine, choline not only donates methyl groups, but also performs specific metabolic functions in animals, in which it cannot be replaced by betaine. Choline is contained in phospholipids which are important structural components of cell membranes. Choline is a precursor of acetylcholine, a substance essential for nerve impulse transmission. It also participates in fat metabolism in the liver (Craig, 2004; Kidd et al., 1997; Simon, 1999).

\section{Osmoprotectant}

Betaine, together with sorbitol, mannitol, glycerol, arabitol, saccharose, taurine, sarcosine and glycerophosphocholine, belongs to a group of organic compounds termed compatible osmolytes. They can be accumulated in high concentrations in the cytoplasm, thus preventing the occurrence of osmotic pressure across the cell membrane and an excessive increase in electrolyte concentrations. Apart from its osmotic activity, betaine alleviates the toxic effects of urea when its concentrations reach dangerous levels, thus acting as an osmoprotectant (Więckowski and Zabłocki, 1996).

The osmoregulation-related properties of betaine were first reported in bacteria whose growth was inhibited by high concentrations of salts (Le Rudulier et al., 1984), and further confirmed by studies on plants (McNail et al., 1999) and fish (Virtanen et al., 1989). Betaine protects plant tissues against freezing, drought and salt stress (Zulkifili et al., 2004). According to Zabaras-Krick (1997), betaine shows the characteristics of a dipolar zwitterion resulting in osmoprotective properties. Osmotic stress may be caused by disease, malnutrition or inadequate environmental conditions. Accumulated betaine permits metabolic activity under conditions that 
would normally cause impairment of cell functions. Betaine has been found to neutralize the inhibition of cell protein synthesis and to enhance the proliferation of isolated cells subjected to hyperosmotic shock (Petronini et al., 1992). Osmotic protection is observed not only in animals that accumulate betaine formed by oxidation of choline, but also in those fed betaine-supplemented diets (Virtanen, 1995).

The functions of water inside the cell are often underestimated. Water plays a key role in cellmetabolism. Maintaining a stable water level requires high energy expenditures. The basic regulatory mechanism is simple osmosis, in which water transport into and out of the cell is controlled by the concentration gradient of salt and solute between the intra- and extracellular space. When the conditions of salt and solute concentrations are inadequate, the sodium-potassium pump is used to maintain water balance in the cell. This mechanism requires more energy than the action of organic osmoprotectants. At the same time, an increase in the concentrations of inorganic ions (sodium, potassium, chlorides) is limited by their destabilizing effect on protein structure and enzyme functions. Betaine, as an organic osmotic compound, has been shown to retain water inside the cell at lower energy expenditures. Therefore, betaine added to feed allows reducing energy requirements for maintenance (Partridge, 2003).

\section{Lipid metabolism}

Numerous studies suggest that lipid metabolism is also affected by betaine (Hanczakowska et al., 1999; Huang et al., 2008; Rojas-Cano et al., 2011; Sales, 2011; Yang et al., 2009), which is considered to be a lipotropic compound. Betaine indirectly stimulates the synthesis of carnitine necessary for the transport of longchain fatty acids to mitochondria, where they are oxidized (Zabaras-Krick, 1997).

According to some authors, betaine enables decreasing the amount of adipose tissue through the stimulation of fatty acid oxidation and contribution to the synthesis of carnitine, as mentioned above (Nakev et al., 2009; Saunderson and McKinlay, 1990). Other observations have confirmed that betaine reduces carcass fat concentration in pigs (Fernandez-Figares et al., 2002), revealing at the same time that the addition of $0.5 \%$ betaine has no impact on the oxidation and utilization of palmitic acid. This suggests that the effect of betaine on lipid metabolism could be related to mechanisms other than oxidation (Wray-Cahen et al., 2004). Löest et al. (2002) found that betaine may decrease the demand for choline methyl groups, thus increasing choline availability for lipid metabolism. This was supported by the findings of Yao and Vance (1989).

\section{Effect of betaine on energy utilization}

According to some authors, betaine supplementation in pig nutrition brings the best results when the ration has a low energy content. Experiments performed at the University of Kentucky (Cromwell et al., 2003) have shown that betaine supplementation is most effective in low-energy diets. The authors noted an improvement in daily gains (by 4\%) and in carcass quality, a decrease in backfat thickness measured using real-time ultrasound, and an increase in carcass leanness. In the previous studies of the same authors (Cromwell et al., 2000), supplementation of low-energy 
diets with betaine $(0.075$ or $0.125 \%)$ did not improve daily gains, while the average feed to gain ratio $(\mathrm{F} / \mathrm{G})$ and selected parameters of carcass quality (backfat thickness and lean content of the carcass) indicated a positive effect of such supplementation. However, no such effects were observed following the inclusion of $0.2 \%$ betaine.

Matthews et al. (1998) reported that betaine increased average daily gain (ADG) in pigs fed diets with low protein and energy levels and diets meeting the nutrient requirements of pigs, but decreased $\mathrm{ADG}$ in pigs fed diets with a low protein content and an adequate energy concentration and diets with an adequate protein content and a low energy concentration. Betaine also increased ADG in pigs fed $80 \%$ of ad libitum intake, but did not affect ADG in pigs provided feed on an ad libitum basis (Casarin et al., 1997).

Zabaras-Krick (1997) also shares the opinion that betaine supplementation increases the energy value of diets. Several experiments have been conducted on growing gilts and hogs to verify the above hypothesis. F/G values were found to improve in animals fed betaine-supplemented diets. Pigs given betaine were characterized by lower values of backfat thickness, by $20 \%$ on average. Carcass leanness also increased, to a higher degree in gilts than in hogs. The addition of betaine to feed improved energy availability, by 5 to $8 \%$.

German researchers whose findings were cited by Partridge (2002) examined the effect of betaine added to diets with a decreased energy concentration on fattening results and carcass quality parameters in growing pigs ( $30 \mathrm{~kg}$ to $120 \mathrm{~kg}$ body weight). The level of digestible energy (DE) was reduced in experimental groups relative to control groups, by $4.3 \%$ in the first experiment and by $3 \%$ in the second experiment. Experimental animals received no choline chloride, whereas amino acid levels were identical in all groups. In the first experiment, ADG were higher in growing (729 g) and finishing $(828 \mathrm{~g})$ pigs fed low-energy betaine-supplemented diets, in comparison with control animals (697 g and $809 \mathrm{~g}$, respectively). The differences were statistically significant. The results of the second experiment on finishing pigs indicated that betaine exerted a positive influence on growth rate when energy concentration was decreased, but the observed differences were non-significant. The lean content of the carcass was higher in experimental groups than in control groups in both experiments. Schrama et al. (2003) studied the effect of betaine on energy metabolism in growing pigs. Energy concentration was decreased in experimental diets, while amino acids were balanced so as to determine the influence of betaine not related to its function of a methyl donor. During the experimental period betaine reduced heat production and energy requirements for maintenance, which consequently increased energy retention. Moreover, the difference in heat production between animals of experimental and control groups increased with time. According to the authors, dietary betaine supplementation affected energy metabolism in two ways: by reducing heat production and by changing the lipid/protein deposition ratio, to the advantage of protein. The authors suggested that due to its osmolytic properties, betaine could reduce energy expenditures for the ion pump, particularly in the cells of the gastrointestinal tract. This opinion is also shared by Simon (1999).

Studies were also conducted on growing-finishing pigs to determine the effect of betaine and enzymatic preparations added to diets with low concentrations of 
energy and amino acids on body weight gains and feed conversion (Szramko et al., $2006 \mathrm{~b})$. Betaine added to diets $(1.25 \mathrm{~kg} / \mathrm{t})$ enabled reducing their energy level by $4.5 \%$ with no negative impact on the body weight gains of growing-finishing pigs. Betaine supplementation had a positive effect on ME utilization per $\mathrm{kg}$ of weight gain. Diets with reduced (by 2.5\%) levels of energy and amino acids, supplemented with feed enzymes, did not decrease the production results (ADG and F/G) of growing-finishing pigs. The addition of betaine $(1.25 \mathrm{~kg} / \mathrm{t})$ and enzymatic preparations allowed reducing the concentrations of energy and amino acids in diets, by $7 \%$ and $2.5 \%$ respectively, with no negative influence on $\mathrm{ADG}$ and $\mathrm{F} / \mathrm{G}$.

Siljander-Rasi et al. (2003) compared the effect of different levels of betaine and its precursor choline on the performance and carcass traits of pigs. The animals were offered diets supplemented with different doses of betaine $(250,500$ or $1000 \mathrm{mg} / \mathrm{kg})$ and choline chloride $(578,1155$ or $2310 \mathrm{mg} / \mathrm{kg})$. The concentration of digestible energy in diets was decreased to $12.3 \mathrm{MJ} / \mathrm{kg}$. ADG and F/G improved linearly with an increase in betaine content, while choline had no influence on the investigated parameters.

Cromwell et al. (1999) examined the efficiency of betaine added to energy-restricted diets for growing-finishing pigs. Over the experimental period, the animals received diets differing in energy levels (13.89 or $13.28 \mathrm{MJ} \mathrm{ME} / \mathrm{kg}$ ) and supplemented with betaine in the amount of $1.14 \mathrm{~g} / \mathrm{kg}$. Betaine improved ADG and F/G in pigs fed a low-energy diet, compared to those offered a diet with a sufficient amount of energy. The lowest backfat thickness $(18.9 \mathrm{~mm})$ was reported in pigs given a low-energy betaine-supplemented diet. In the group of pigs offered betaine-supplemented feed with an adequate concentration of energy, backfat thickness was $20.6 \mathrm{~mm}$. In another experiment of this study, supplemental betaine decreased backfat thickness to a comparable degree in both experimental groups. Low-energy betaine-supplemented diets contributed to an increase in carcass lean percentage. It has been estimated that betaine decreased backfat thickness by $5.5 \%$ and increased carcass leanness by $1 \%$ in pigs fed diets with an adequate energy level, whereas in animals given energy-limited diets backfat thickness decreased by $5.3 \%$ and carcass leanness increased by $2.3 \%$.

The findings of Van Milgen et al. (2003) do not support the results of the above studies. An analysis of energy metabolism parameters, performed by these authors, showed that betaine had no impact on body energy partitioning. Haydon et al. (1995) reported that betaine improved ADG and ADFI (average daily feed intake) in pigs fed high-energy diets, but decreased ADG and ADFI in pigs fed low-energy diets. The findings of Gagucki and Skomiał (2000) are also only partly consistent with numerous experimental data pointing to the beneficial influence of supplemental betaine on carcass quality parameters. These authors demonstrated that the inclusion of betaine in energy-restricted diets resulted in a $0.57 \mathrm{~cm}$ increase in average backfat thickness, a decrease in the meat content of primal cuts and higher carcass fatness.

Available literature provides scant information on the effect of betaine on the growth performance and carcass traits of young growing pigs with live body weight of up to $30-60 \mathrm{~kg}$. Fernandez-Figares et al. (2002) conducted an experiment under conditions of restricted feeding ( $69 \%$ of the predicted ad libitum intake) to deter- 
mine the effect of different levels of betaine $(0.125,0.250$ or $0.500 \%)$ in diets on the growth rate and carcass quality parameters in growing pigs. It was found that dietary betaine supplementation had no influence on daily gains and the feed conversion ratio in pigs growing from 36 to $64 \mathrm{~kg}$, fed nutrient-restricted diets. However, betaine positively affected carcass traits, decreasing the total concentration of carcass fat, increasing the total concentration and deposition rate of carcass protein, and improving lean gain efficiency. There was a linear trend towards reduced fat as the concentration of dietary betaine increased. Pigs receiving $0.5 \%$ betaine had a $10 \%$ lower concentration of carcass fat, in comparison with the control group. Backat depth (P3) also decreased with an increase in betaine doses.

Other experiments involving growing pigs (20 kg BW) fed at a level of $95 \%$ of ad libitum energy intake revealed a synergistic action when betaine and conjugated linoleic acid (CLA) were administered together. Betaine or CLA alone did not affect the growth performance of animals. However, betaine $(0.5 \%)+$ CLA $(1 \%)$ increased $\mathrm{ADG}$, daily gains and protein deposition relative to $\mathrm{ME}$ intake, compared with control animals (Fernandez-Figares et al., 2008).

In a study conducted by Szramko et al. (2006 a), 584 growing pigs with average live body weight of about $15 \mathrm{~kg}$ were divided into four groups. Pigs of the control group (I) were fed a standard diet, the composition of which satisfied the nutrient requirements of animals. In group II the energy level of a betaine-supplemented diet was reduced by $4.5 \%$ relative to the control group. In group III the levels of ME and AA in a diet containing feed enzymes ( $\beta$-glucanase, $\beta$-xylanase and $\alpha$-amylase) were reduced by $2.5 \%$ in comparison with the control group. Pigs from group IV received a diet supplemented with both betaine and feed enzymes. The energy value and the amino acid content of this diet were reduced by $7.0 \%$ and $2.5 \%$, respectively. It was found that diets with reduced levels of energy or energy and amino acids, supplemented with betaine, feed enzymes or betaine and feed enzymes, fed to growing pigs, had no negative effect on production results. A tendency towards better production results was even observed in the experimental groups. Betaine added to diets with a reduced energy concentration had a beneficial influence on ME utilization per $\mathrm{kg}$ of body weight gain.

\section{Conclusion}

In order to meet changing consumer preferences associated with a growing demand for safe foods, new solutions are searched for in order to improve the efficiency of pig production while maintaining high pork quality. In view of the above, betaine has recently gained increasing attention as a natural feed additive in pig nutrition. It has been found that dietary betaine supplementation positively affects carcass quality traits, as reflected in both reduced backfat thickness and increased lean percentage. An improvement in body weight gains and in the feed conversion ratio in pigs offered betaine-containing diets has been also reported by numerous authors. It has been well documented that betaine can partly replace methionine or choline in diets for pigs, and that it can act as a potent osmoprotectant. Moreover, betaine may play a significant role in energy metabolism, as suggested by the results of some studies in which the demand for energy was reduced in pigs receiving betaine-sup- 
plemented diets. In view of the above, betaine supplementation may have important practical implications. When added to low-energy pig diets, betaine contributes to an improvement in overall production results. Pigs fed betaine-supplemented diets are able to make better use of their genetic potential as betaine enables them to save part of maintenance energy.

\section{References}

C a s a r in A., F o r a t M., Z a b a r a s - K r i c k B. (1997). Interrelationships between betaine (Betafin$\mathrm{BCR}$ ) and level of feed intake on the performance parameters and carcass characteristics of growing-finishing pigs. J. Anim. Sci., 75 (Suppl. 1), p. 75.

C r a i g S.A.S. (2004). Betaine in human nutrition. Am. J. Clin. Nutr., 80: 539-549.

Cromwell G.L., Lindemann M.D., Coffey R., Parker G., Petty A., Monegue J., Randolph J., Laurent K. (2003). Dietary supplement has marginal benefits. National Hog Farmer, p. 2.

Cromwe 11 G.L., Lind e m a n n M.D., R a n d o lph J.R., L a u re n t K.M., P a r k er G.R., C of fe y R.D. (2000). Effects of betaine levels in reduced energy diets for finishing pigs. J. Anim. Sci., 78 (Suppl. 1), p. 189.

Cromwell G.L., Lindemann M.D., Randolph J.R., Monegue H.J., Laurent K.M., P a r k e r G.R. (1999). Efficacy of betaine as a carcass modifier in finishing pigs fed normal and reduced energy diets. J. Anim. Sci., 77 (Suppl. 1), p. 179.

Eklund M., B auer E., W a matu J., Mosenthin R. (2005). Potential nutritional and physiological functions of betaine in livestock. Nutr. Res. Rev., 13: 31-48.

F e n g J., Li u X., W a n g Y.Z., X u Z.R. (2006). Effects of betaine on performance, carcass characteristics and hepatic betaine-homocysteine methyltransferase activity in finishing barrows. Asian-Austrial. J. Anim. Sci., 19 (3): 402-405.

Fernández-Fígares I., Conde-Aguilera J.A., Nieto R., Lachica M., Aguiler a J.F. (2008). Synergistic effects of betaine and conjugated linoleic acid on growth and carcass composition of growing Iberian pigs. J. Anim. Sci., 86: 102-111.

Fernández-Fígares I., Wray-Cahen D., Steele N.C., Campbell R.G., Hall D.D., Virtanen E., Caperna T.J. (2002). Effect of dietary betaine on nutrient utilization and partitioning in the young growing feed-restricted pig. J. Anim. Sci., 80: 421- 428.

F in k e l s t e i n J.D., M a r t i n J.J. (1984). Methionine metabolism in mammals. Distribution of homocysteine between competing pathways. J. Biol. Chem., 259, 15: 9508-9513.

F in k e l s t e in J.D., M a r t i n J.J. (1986). Methionine metabolism in mammals. Adaptation to methionine excess. J. Biol. Chem., 261, 4: 1582-1587.

G a g u c k i M., S k o mi ał J. (2000). Effects of adding betaine to diets with different energy level on slaughter value and composition of loin and fat tissues in growing-finishing pigs (in Polish). Rocz. Nauk. Zoot., Supl. 6: 162-166.

Hanczakowska E., Urbańczyk J., Świą tkiewicz M. (1999). The efficiency of betaine and organic compounds of chromium in fattening of pigs with ad libitum or restricted feeding. Ann. Anim. Sci., 26, 4: 263-274.

H a y d o n K.D., C a m p b e 11 R.G., Pr i n c e T.J. (1995). Effect of dietary betaine additions and amino:calorie ratio on performance and carcass traits of finishing pigs. J. Anim. Sci., 73 (Suppl. 1), p. 83 .

H u a n g Q.C., Xu Z.R., H a n X.Y., Li W.F. (2007). Effect of betaine on growth hormone pulsatile secretion and serum metabolites in finishing pigs. J. Anim. Physiol. Anim. Nutr., 91: 85-90.

Huang Q.C., Xu Z.R., H an X.Y., Li W.F. (2008). Effect of dietary betaine supplementation on lipogenic enzyme activities and fatty acid synthase mRNA expression in finishing pigs. Anim. Feed Sci. Technol., 140: 365-375.

K i d d M.T, F e r k e t P.R., G a r li c h J.D. (1997). Nutritional and osmoregulatory functions of betaine. World Poultry Sci. J., 53: 125-139. 
Le Rudulier D., Strom A.R., Dandekar A.M., Smith L.T., Valentine R.C. (1984). Molecular biology of osmoregulation. Science, 224: 1064-1068.

L ow ry K.R., I zqui erdo Q.A., B a ker D.H. (1987). Efficacy of betaine relative to choline as a dietary methyl donor. Poultry Sci., 66: p. 135.

L ö e s t C.A., T i t g e m e y e r E.C.,D r o u i 11 a r d J.S.,C o e t z e r C.M.,H u n t e r R.D.,B in d e 1 D.J., L a m bert B.D. (2002). Supplemental betaine and peroxide-treated feather meal for finishing cattle. J. Anim. Sci., 80: 2234-2240.

Mat thew s J.O., S o u the r n L.L., P o n t i f J.E., H i g b i e A.D., B i d n e r T.D. (1998). Interactive effects of betaine, crude protein, and net energy in finishing pigs. J. Anim. Sci., 76: 2444-2455.

M c N e i 1 S.D., N u c c i o M.L., H a n s o n A.D. (1999): Betaines and related osmoprotectants. Targets for metabolic engineering of stress resistance. Plant. Physiol., 120: 945-949.

N a k e v J., P o p o va T., V a s i l e v a V. (2009). Influence of dietary betaine supplementation on the growth performance and carcass characteristics in male and female growing-finishing pigs. Bulg. J. Agric. Sci., 15: 263-268.

O d l e J., H e o K.N., Li n X. (2000). The role of carnitine and betaine in lean growth modulation of swine. Asian-Austral. J. Anim. Sci., 13, Special Issue, pp. 386-395.

Over land M., R orvik K.A., S kre de A. (1999). Effect of trimethylamine oxide and betaine in swine diets on growth performance, carcass characteristics, nutrient digestibility, and sensory quality of pork. J. Anim. Sci., 77: 2143-2153.

Partridge G.G. (2003). Betaine's dual role. Pig Progress, 19, p. 10.

Petronini P.G., De Angelis E.M., Borghetti P., Borghetti A.F., Whe eler K.P. (1992). Modulation by betaine of cellular responses to osmotic stress. Biochem. J., 282: 69-73.

Puchala R., Zabielski R., Lesniewska P., Gralak W., Kiela P., Barej W. (1998). Influence of duodenal infusion of betaine or choline on blood metabolites and duodenal electrical activity in Friesian calves. J. Agric. Sci., 131: 321-327.

R e m u s J.C., V irt a n e n E. (1996). Use of liquid betaine in low methionine diets for broilers. Poultry Sci., 75, (Suppl. 1), p. 35.

Rojas-Cano M.L., Lara L., Lachica M., Aguilera J.F., Fernandez-Figares I., (2011). Influence of betaine and conjugated linoleic acid on development of carcass cuts of Iberian pigs growing from 20 to $50 \mathrm{~kg}$ body weight. Meat Science, 88: 525-530.

Sa arinen M.T., Kettunen H., Pulliainen K., P euranen S., Tiihonen K., Remus J. (2001). A novel method to analyze betaine in chicken liver: effect of dietary betaine and choline supplementation on the hepatic betaine concentration in chick. J. Agric. Food Chem., 49: 559-563.

S a le s J. (2011). A meta-analysis of the effects of dietary betaine supplementation on finishing performance and carcass characteristics of pigs. Anim. Feed Sci. Technol., 165: 68-78.

S a un d e r s o n C.L., M a c K in l a y J. (1990). Changes in body-weight, composition and hepatic enzyme activities in response to dietary methionine, betaine and choline levels in growing chicks. Brit. J. Nutr., 63: 339-349.

Schrama J.W., He etkamp M.J., S immins, Gertis W.J.J. (2003). Dietary betaine supplementation affects energy metabolism of pigs. J. Anim. Sci., 81: 1202-1209.

S chrama J.W., S i m mins P., Gerrits W.J.J. (2001). Effect of dietary betaine supplementation on energy partitioning in pigs. J. Anim. Sci., 79 (Suppl. 1), p. 184.

Siljander-Rasi H., P euranen S., Ti ihonen K., Virtanen E., Kettunen H., A lavi u h k o la T., S i m m in s P.H. (2003). Effect of equi-molar dietary betaine and choline addition on performance, carcass quality and physiological parameters of pigs. Anim. Sci., 76: 55-62.

S i m on J. (1999). Choline, betaine and methionine interactions in chickens, pigs and fish (including crustaceans). World Poultry Sci. J., 55: 353- 374.

S w a in B.K., J o hri T.S. (2000). Effect of supplemental methionine, choline and their combinations on the performance and immunoresponse of broilers. Brit. Poultry Sci., 41: 83-88.

Szramko E., Lipiński K., Purwin C., Tywończuk J., Antoszkiewicz Z. (2006 a). Possibility to reduce the levels of energy and amino acids in diets for growing pigs supplemented with betaine and feed enzymes. Ann. Anim. Sci., Suppl. 2/1: 215-219.

Szramko E., Lipiński K., Purwin C., Tywończuk J., Antoszkiewicz Z. (2006 b). Response of growing-finishing pigs to reduced levels of energy and amino acids in diets supplemented with betaine and feed enzymes. Pol. J. Natur. Sci., Suppl., 3: 369-376. 
V a n Milg e n J., N oble t J., D u b o is S. (2003). Effect of betaine on energy partitioning in growing pigs. J. Anim. Sci., 81, (Suppl. 1), p. 141.

Vir t a n e n E. (1995). Piecing together the betaine puzzle. Feed Mix, 3, 1: 12-17.

Virtanen E., Junnila J., Soivio A. (1989). Effects of food containing betaine/amino acid additive on the osmotic adaptation of young Atlantic salmon, Salmo solar L. Aquaculture, 83: $109-122$.

Virtanen E., Remus J., Rosi L., McNaughton J., Augustine P. (1996). The effect of betaine and salinomycin during coccidosis in broilers. Poultry Sci., 75 (Suppl. 1), p. 149.

Wi ęc kowski M.R., Z a błocki K. (1996). Osmolality and regulation in kidney cells (in Polish). Post. Biochem., 42, 2: 167-177.

W o y e n g o T.A., S a n d s J.S., Gu en te r W., N y a c h ot i C.M. (2008). Nutrient digestibility and performance responses of growing pigs fed phytase- and xylanase-supplemented wheat-based diets. J. Anim. Sci., 86: 848-857.

Wray-Cahen D., Fernandez-Figares I., Virtanen E., Steele N.C., Carpena T.J. (2004). Betaine improves growth, but does not induce whole body or hepatic palmitate oxidation in swine (Sus scrofa domestica). Comp. Biochem. Physiol., Part A, 137, 1: 131-140.

Y a ng H.S., L e e J.I., J o o S.T., P a r k G.B. (2009). Effects of dietary glycine betaine on growth and pork quality of finishing pigs. Asian-Austral. J. Anim. Sci., 22: 706-711.

Y a o Z., V a n c e D. (1989). Head group specificity in the requirement of phosphatidylcholine biosynthesis for low density lipoprotein secretion from cultured hepatocytes. J. Biol. Chem., 264: $11373-11380$.

$\mathrm{Z}$ a b a r a s-K ri ck B. (1997). Betaine improves energy utilisation. Intern. Pig. Topics., 12, 5: 12-14.

Z e i s e 1 Z.R., M a r M.H., H ow e J.C., Hold e n J.M. (2003). Concentration of choline-containing compounds and betaine in common foods. J. Nutr., 133: 1302-1307.

Zulkifli I., Mysahra S.A., J in L.Z. (2004). Dietary supplementation of betaine (Betafin ${ }^{\circledR}$ ) and response to high temperature stress in male broiler chickens. Asian-Austral. J. Anim. Sci., 17, 2: 244-249.

Accepted for printing 20 III 2012

\section{KRZYSZTOF LIPIŃSKI, EWA SZRAMKO, HEINZ JEROCH, PAULIUS MATUSEVIČIUS}

\section{Wpływ betainy na wykorzystanie energii u rosnących świń - przegląd piśmiennictwa}

\section{STRESZCZENIE}

Jedną z dobrze poznanych funkcji biologicznych betainy jest dostarczanie organizmowi grup metylowych. Z tego względu uważa się, że betaina może zastępować część choliny i metioniny w dawkach pokarmowych. Inną rolą betainy, także potwierdzoną już w licznych badaniach naukowych, jest jej udział w zachowaniu prawidłowej równowagi osmotycznej. Betaina, jako organiczny związek osmotyczny, reguluje gospodarkę wodną organizmu, co z kolei wpływa stabilizująco na metabolizm wielu tkanek, zwłaszcza w obrębie przewodu pokarmowego. Betaina, dostarczając grup metylowych, niezbędnych do prawidłowego przebiegu szeregu przemian $\mathrm{w}$ organizmie, jest pośrednio zaangażowana również w metabolizm tłuszczu.

Obecnie uważa się, że betaina dzięki pełnionym funkcjom metabolicznym, może mieć również istotne znaczenie w przemianach energetycznych świń. Szczególną uwagę zwracają wyniki doświadczeń, w których korzystne działanie dodatku betainy obserwowano przy obniżonym poziomie energii w mieszankach. 